\title{
SISTEM INFORMASI PERPUSTAKAAN BERBASIS WEB PADA SMA SANTO YOSEPH MEDAN
}

\author{
Sarah Silaen, Roni J. Simamora, Mendarissan Aritonang \\ Universitas Methodist Indonesia, Medan, Indonesia \\ ronimor4@gmail.com
}

\begin{abstract}
The library is very important in supporting the knowledge and information of students in school because the library is part of the learning resources that must be owned by the school; hence the library is often referred to as the heart of education. At present, the Santo Yoseph Medan High School Library, which is currently processing its library, has not been computerized, making it difficult to process loan transactions and return books, and register as a member and award fines. For this reason, SMA Santo Yoseph Medan requires a library that has a web-based library system. The tool used to design this library information system is to use the PHP and MySql programming languages. The results of this web-based library information system design are expected to help library administrators in the process of borrowing and returning books, processing book data and members, and making library data reports.
\end{abstract}

Keyword: Information Systems, Website, Library.

\section{PENDAHULUAN}

Perpustakaan sangat penting dalam menunjang pengetahuan dan informasi peserta didik di sekolah karena perpustakaan merupakan bagian dari sumber belajar yang harus dimiliki sekolah, maka dari itu perpustakaan kerap kali disebut sebagai jantungnya pendidikan. Di lingkungan sekolah, perpustakaan merupakan bagian yang tidak dapat dipisahkan dari proses pendidikan. Perpustakaan merupakan sarana, baik bagi peserta didik ataupun bagi guru sebagai pemustaka dalam menunjang proses belajar mengajar di sekolah. Komputer sesuai dengan fungsinya adalah sebagai alat untuk mengolah data menjadi informasi yang lebih baik sehingga lebih efektif. Perpustakaan SMA Santo Yoseph Medan yang saat ini pengolahan perpustakaannya masih dengan menggunakan buku besar, seperti daftar anggota, proses peminjaman dan pengembalian buku, administrasi jumlah, buku, dan pemberian denda. Hal tersebut menyebabkan hasil yang kurang teliti dalam peminjaman dan pengembalian buku, serta seringnya kesalahan perhitungan denda kepada siswa yang terlambat mengembalian buku.

Pemanfaatan sistem informasi di perpustakaan sudah banyak diterapkan di sekolah, seperti yang diterakan di SMP Negeri 1 Pakuhaji Tangerang [1], sistem informasi perpustakaan di SMP Negeri 97 Jakarta [2] dan sistem informasi perpustakaan di SMP Negeri 1 Donorojo Pacitan [3]. Dari ketiga sistem informasi perpustakaan yang diimplementasikan tersebut dapat meningkatkan efisiensi dan efektifitas kerja pegawai perpustakaan dalam pendataan koleksi. Berdasarkan pemaparan latar belakang diatas, penulis bertujuan untuk merancang sistem informasi perpustakaan berbasis web pada SMA Santo Yoseph Medan yang diharapkan mampu untuk meningkatkan pelayanan dan kinerja perpustakaan sekolah. Dengan adanya perubahan sistem pelayanan informasi perpustakaan yang masih menggunakan buku besar menjadi sistem informasi perpustakaan berbasis web ini diharapkan segala aktifitas sistem tersebut memberikan kemudahan bagi perpustakaan SMA Santo Yoseph Medan untuk melakukan kegiatan peminjaman dan pengembalian buku kepada siswa yang bersangkutan serta perhitungan denda.

\section{TINJAUAN PUSTAKA \\ Sistem Informasi}

Sistem adalah kumpulan atau grup dari sub sistem/bagian/komponen apapun baik fisik ataupun non fisik yang saling berhubungan satu sama lain dan bekerja sama secara harmonis untuk mencapai satu tujuan tertentu [4]. Sedangkan dari sumber lain sistem diartikan sebagai suatu rangkaian yang terdiri dari dua atau lebih komponen yang saling berbungan dan saling berinteraksi satu sama lain untuk mencapai tujuan dimana sistem terbagi dalam sub sistem yang lebih kecil yang mendukung sistem yang lebih besar [5].

Informasi adalah data yang telah diorganisasikan dan telah memiliki kegunaan dan manfaat [6]. Menurut [7], informasi adalah hasil dari pengolahan data, akan tetapi tidak semua hasil dari pengolahan tersebut bisa menjadi informasi, hasil pengolahan data yang tidak memberikan makna atau arti serta tidak bermanfaat bagi seseorang bukanlah merupakan informasi bagi orang tersebut.

Sistem informasi adalah cara-cara yang untuk mengumpulkan, memasukkan, dan mengolah serta menyimpan data dan cara-cara yang diorganisasikan untuk menyimpan, mengolah, mengendalikan dan melaporkan informasi sedemikian rupa sehingga sebuah organisasi dapat mencapai tujuan yang telah di tetapkan [6][8]

\section{Perpustakaan}

Perpustakaan adalah tempat, gedung, ruang yang disediakan untuk pemeliharaan dan penggunaan koleksi buku dan sebagainya. Koleksi buku, majalah, dan bahan kepustakaan lainnya yang disimpan untuk dibaca [9].

\section{Data Flow Diagram (DFD)}

Data Flow Diagram (DFD) adalah representasi grafik yang menggambarkan aliran informasi dan transformasi 
informasi yang diaplikasikan sebagai data yang mengalir dari masukan (input) dan keluaran (output) [10].

\section{Flowchart}

Flowchart (Bagan Alir) adalah bagan yang menggambarkan urutan instruksi proses dan hubungan satu proses dengan proses lainnya menggunakan simbol-simbol tertentu [11].

\section{Entity Relationship Diagram}

Entity Ralationship Diagram (ERD) adalah tools yang digunakan untuk melakukan pemodelan data secara abstrak dengan tujuan untuk mendeskripsikan atau menggambarkan struktur dari data yang digunakan [12].

\section{METODE PENELITIAN}

\section{Metode Pengumpulan Data}

Metode pengumpulan data yang dilakukan oleh penulis meliputi:

a. Metode Observasi

Pengumpulan data dengan pengamatan langsung dan pencatatan secara sistematis terhadap obyek yang akan diteliti.

b. Metode Wawancara

Teknik pengumpulan data yang dilakukan melalui tatap muka dan tanya jawab langsung antara penulis kepada pegawai yang mengelola perpustakaan SMA Santo Yoseph Medan, dan keterangan-keterangan lain yang berhubungan dengan perpustakaan.

c. Studi Kepustakaan
Metode yang dilakukan dengan cara mengumpulkan, membaca, dan mempelajari data-data yang ada dari berbagai media, seperti buku-buku, hasil karya tulis, jurnal-jurnal, penelitian atau artikel-artikel dari internet yang berhubungan dengan masalah yang dibahas.

\section{Perancangan Sistem}

Perancangan sistem yang dilakukan oleh penulis meliputi tahapan sebagai berikut:

a. Analisis Sistem

Pada tahap ini penulis menganalisis dan membuat suatu sistem perpustakaan SMA Santo Yoseph Medan.

b. Perancangan Sistem

Pada tahap ini penulis akan merancang usulan sistem yang baru, dengan menggunakan perancangan sistem menggunakan pemrograman PHP dan database MySQL.

c. Pembangunan

Pada tahap ini penulis akan membangun sebuah sistem informasi perpustakaan.

d. Testing Sistem

Pengujian yang dilakukan terhadap keseluruhan sistem (secara lengkap).

Diagram konteks yang dirancang dalam pembuatan sistem informasi perpustaaan di SMA Santo Yoseph Medan ditunjukkan pada gambar 1 berikut:

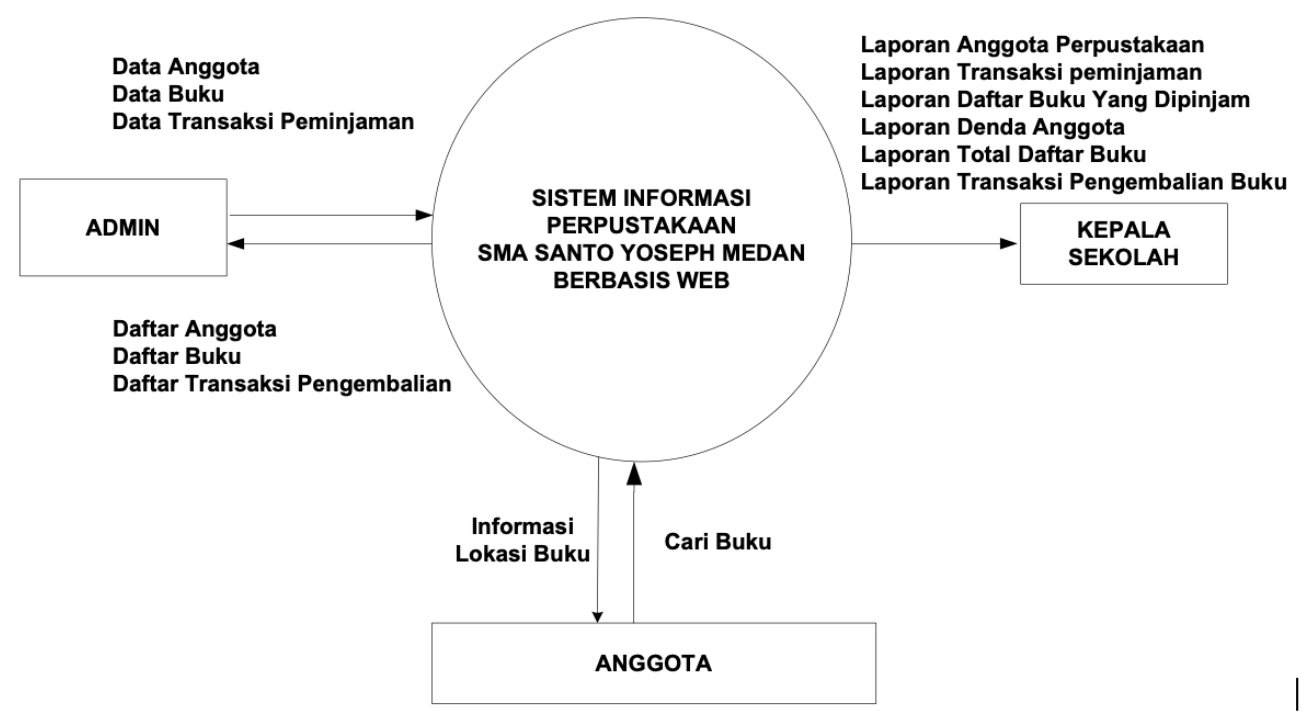

Gambar 1. Diagram Konteks Sistem Usulan 


\section{HASIL DAN PEMBAHASAN \\ Tampilan Login}

Tampilan awal login adalah tampilan pertama pada saat program dijalankan, dimana berisikan Username dan Password. Adapun tampilan awal seperti pada gambar 2 berikut:

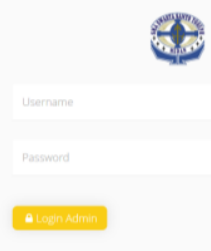

Gambar 2. Tampilan Awal Untuk Login Admin

\section{Tampilan Awal Sistem}

Tampilan ini merupakan tampilan pertama yang secara otomatis terbuka apabila proses login admin berhasil. Tampilan awal halaman admin dapat dilihat seperti pada Gambar 3

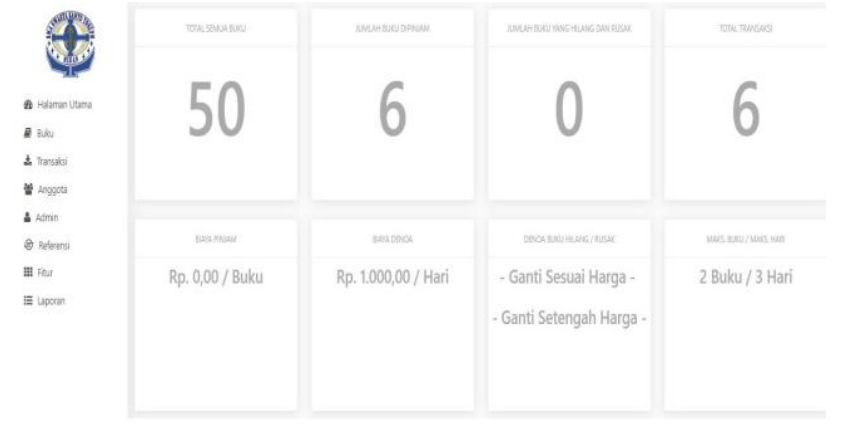

Gambar 3. Tampilan awal halaman sistem

\section{Tampilan Menu Menambah Anggota}

Digunakan untuk menginputkan data anggota satu persatu, menu menambahkan anggota dimasukkan melalui form tambah anggota berupa data nis, nama, jenis kelamin, status, alamat, dan no hp. Adapun tampilan untuk menambah anggota dapat dilihat pada gambar 4

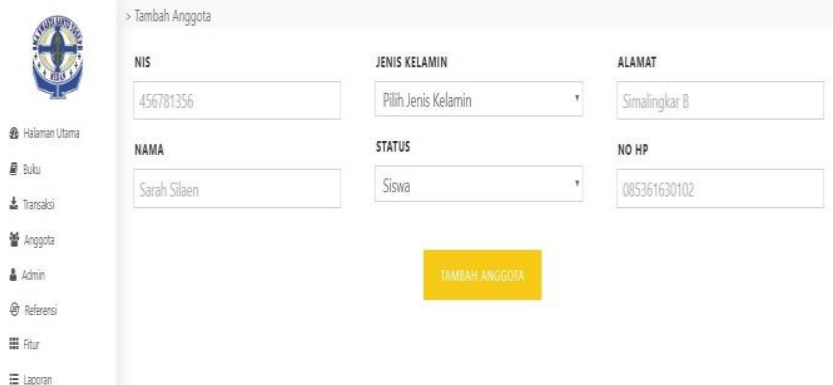

Gambar 4. Tampilan Menu Menambah Anggota

\section{Tampilan Untuk Menambah Buku}

Digunakan untuk menambahkan data buku yang ingin dimasukkan, melalui form tambah buku berupa judul buku, pengarang, isbn, tahun terbit, penerbit, preface, harga, sumber, lokasi, jenis buku, kategori, jumlah buku, serta cover dari buku tersebut. Seperti dapat dilihat seperti pada Gambar 5

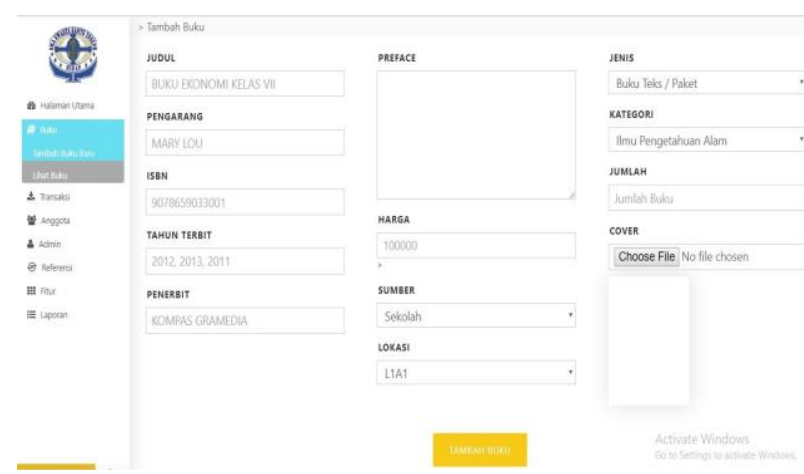

Gambar 5. Tampilan Untuk Menambah Buku

\section{Tampilan Untuk Melakukan Transaksi}

Transaksi adalah proses peminjaman dan pengembalian buku supaya menciptakan kemudahan-kemudahan dalam melakukan semua transaksi yang ada di perpustakaan. Dalam sistem informasi perpustakaan ini mencakup 3 hal yaitu transaksi peminjaman, transaksi pengembalian, serta denda.

Pada sistem perpustakaan ini tanggal pinjam dan tanggal kembali secara otomatis dan batas pengembalian selama 3 hari dari tanggal peminjaman. Adapun tampilan untuk menambah transaksi peminjaman dapat dilihat pada gambar 6

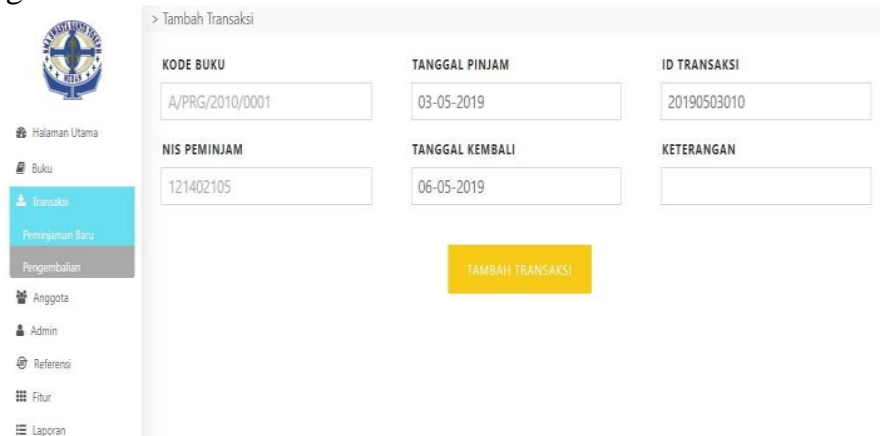

Gambar 6. Tampilan Menu Input Tambah Transaksi

Adapun tampilan sesudah menambah transaksi peminjaman dapat dilihat pada gambar 7

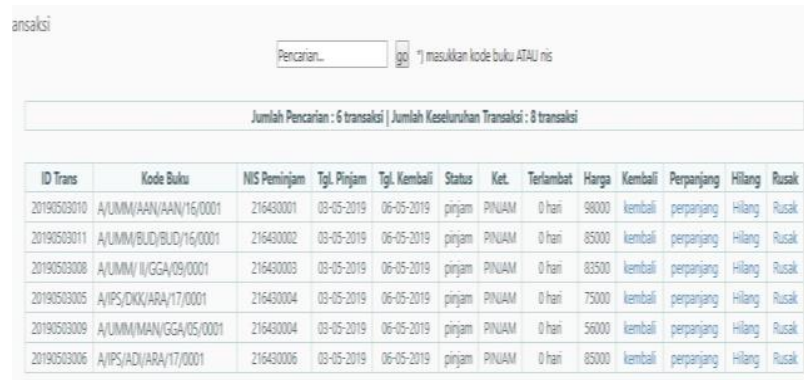

Gambar 7. Tampilan Menu Sesudah Menambah Transaksi

Sesudah admin berhasil menambahkan transaksi peminjaman buku, maka otomatis pada sistem ini, status buku akan berubah secara otomatis menjadi pinjam. 


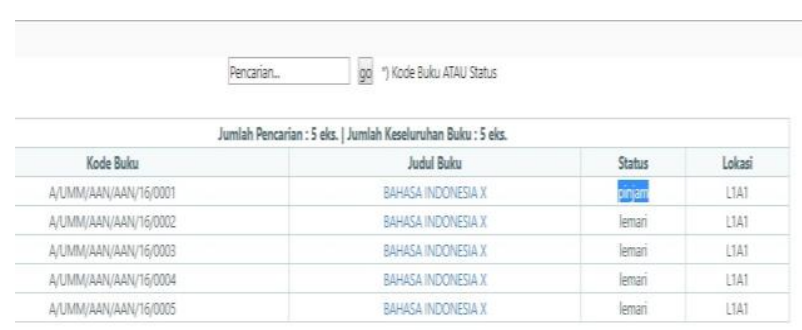

Gambar 8. Tampilan Status Buku Yang Dipinjam

Dalam melakukan transaksi pengembalian buku oleh petugas perpustakaan. Misalnya disini anggota perpustakaan ingin mengembalikan buku yang sudah dipinjam. Maka pada sistem tersebut admin tinggal mengklik transaksi pengembalian. Lalu memasukkan nis (nomor induk siswa) tersebut, lalu mengklik menu kembali apabila buku dikembalikan dalam kondisi tidak rusak, dan apabila buku dikembalikan dalam keadaan rusak atau pun hilang maka admin hanya tinggal mengklik sesuai dengan kondisi buku tersebut dan apabila ingin memperpanjang buku, admin tinggal mengklik menu perpanjang buku, maka otomatis tanggal kembali akan bertambah selama 3 hari kedepan.

Adapun tampilan transaksi pengembalian buku dapat dilihat pada gambar 9

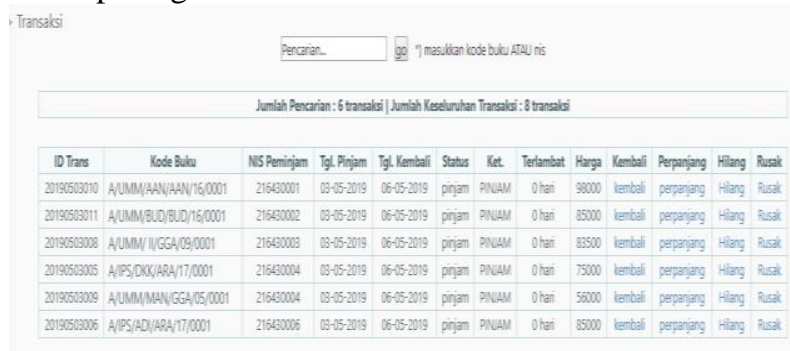

Gambar 9. Tampilan Transaksi Pengembalian Buku

Batas waktu peminjaman buku adalah 3 hari, Apabila siswa ingin memperpanjang waktu peminjaman buku, maka pertama-tama admin akan mengklik tombol transaksi pengembalian dan memasukkan kode buku atau nis dari siswa yang meminjam buku tersebut dan mengklik tombol perpanjang waktu peminjaman buku, maka batas waktu pengembalian buku akan bertambah selama tiga hari secara otomatis.

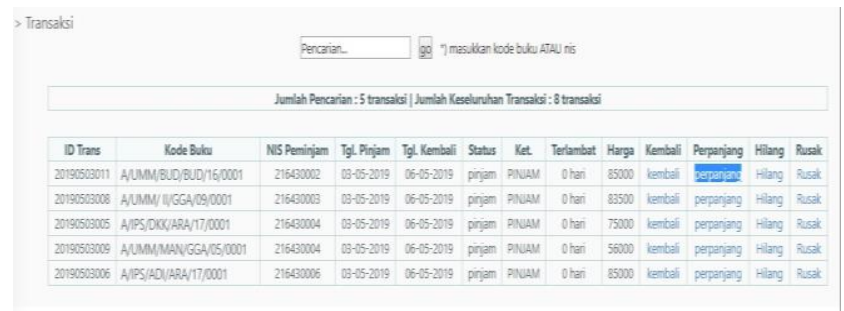

Gambar 10. Tampilan Menu Transaksi Pengembalian Buku

Adapun tampilan sesudah berhasil memperpanjang buku dapat dilihat pada gambar 11

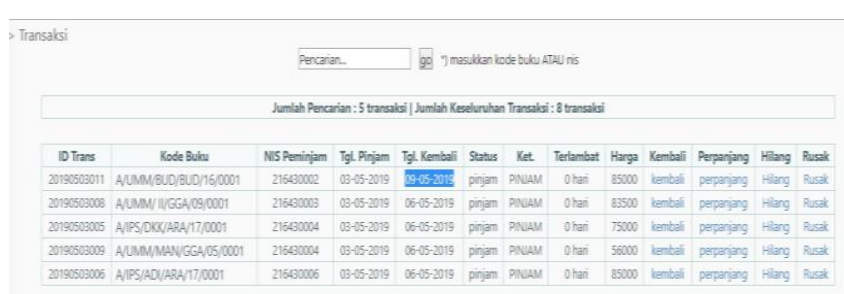

Gambar 11. Tampilan Proses Sesudah Berhasil Memperpanjang Buku

\section{Tampilan Untuk Mengetahui Denda Anggota}

Tidak berbeda dari sebelumnya, Apabila ada siswa yang terlambat mengembalikan buku dari tanggal pengembalian yang sudah ditetapkan, Maka pada sistem tersebut admin tinggal mengklik transaksi pengembalian. Lalu memasukkan nis (nomor induk siswa) tersebut, maka denda akan otomatis menghitung keterlambatan hari nya beserta dendanya.

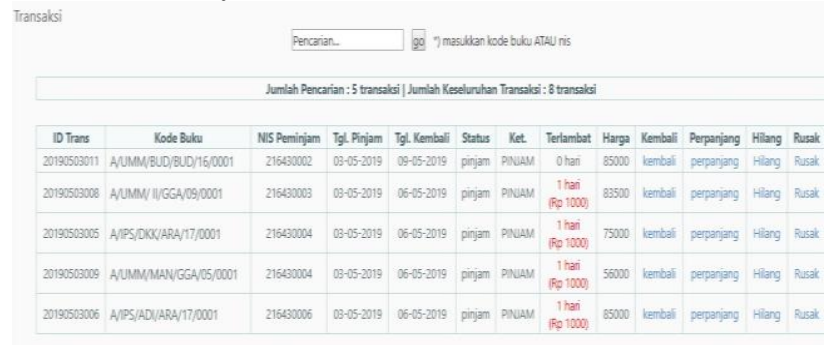

Gambar 12 Tampilan untuk melihat hari

keterlambatan pengembalian dan denda secara otomatis

\section{Tampilan Ubah Pengaturan}

Digunakan untuk mengubah pengaturan biaya denda per buku dan batas waktu peminjaman buku. Adapun tampilan untuk melihat tampilan ubah pengaturan dapat dilihat pada gambar 4.19

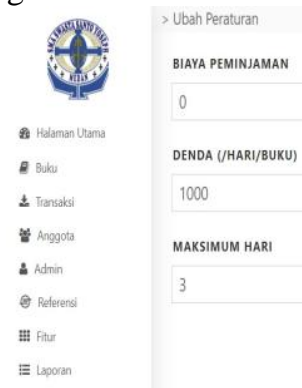

Gambar 13. Tampilan Menu Untuk Ubah Pengaturan

\section{Tampilan Menu Cari Buku Yang dilakukan Siswa}

Digunakan untuk memberikan kemudahan kepada siswa dalam mencari buku yang ingin dipinjam untuk mengetahui lokasi dari buku tersebut tanpa harus mencari buku tersebut ke perpustakaan. Adapun tampilan untuk melakukan pencarian buku dapat dilihat pada gambar 14

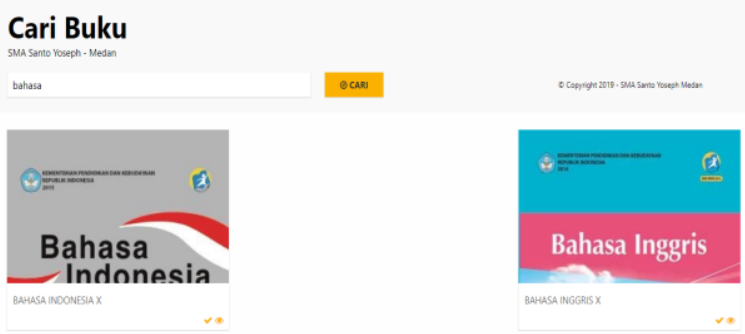

Gambar 14. Tampilan Menu Untuk Mencari Buku 


\section{Laporan Sistem Informasi Perpustakaan SMA Santo Yoseph Medan}

Laporan sistem informasi perpustakaan SMA Santo Yoseph Medan ini terdiri dari laporan anggota, laporan daftar peminjam, daftar buku yang dipinjam, laporan denda, laporan daftar buku total, dan laporan pengembalian. Laporan Untuk melihat nama anggota perpustakaan lengkap dengan id anggota, jenis kelamin, alamat serta nomor HP

\section{LAPORAN ANGGOTA PERPUSTAKAAN}

\begin{tabular}{|c|c|c|c|c|c|}
\hline \multicolumn{6}{|c|}{ SWIM } \\
\hline ID Anggota & Nama & J.K & Status & Alamat & No HP \\
\hline \begin{tabular}{|l|}
216430001 \\
\end{tabular} & ANDRO SIAHAAN & Laki-laki & Siswa & Jl. Jamin Ginting No. 111 & 083196361587 \\
\hline \begin{tabular}{|l|}
216430002 \\
\end{tabular} & ANDRE PURBA & Laki-laki & Siswa & SIMALINGKAR B & 083190909090 \\
\hline 216430003 & SARAH SILAEN & Perempuan & Siswa & Jl. Jamin Ginting No.819 & 082276631442 \\
\hline \begin{tabular}{|l|}
216430004 \\
\end{tabular} & ABDON SIAHAAN & Laki-laki & Siswa & Jl. Sekip & 0833196361587 \\
\hline \begin{tabular}{|l|}
216430005 \\
\end{tabular} & SOFYA C SITOMPUL & Laki-laki & Siswa & JI Kediri No. 70 & 083196361587 \\
\hline \begin{tabular}{|l|l|}
216430006 \\
\end{tabular} & SAMUEL SILALAHI & Laki-aki & Siswa & \begin{tabular}{|l|} 
Jnn Perjuangan No 44 \\
\end{tabular} & 085270707070 \\
\hline
\end{tabular}

$$
\begin{aligned}
& \text { Medan, } 10-04-2019 \\
& \text { Kepala Sekolah }
\end{aligned}
$$

$$
\text { Sr. Frederika Sijabat, SCMM, S.Pd }
$$

Gambar 15. Tampilan Laporan Anggota Perpustakaan

\section{Laporan Transaksi Peminjaman SMA Santo Yoseph Medan}

Laporan Transaksi Peminjaman SMA Santo Yoseph Medan ini adalah laporan untuk mengetahui anggota yang melakukan peminjaman buku yang dilakukan siswa, yang

\begin{tabular}{|c|c|c|c|c|c|c|}
\hline ID Tramsatsi & Kode Buku & ID Anspota & T:al Minjamm & $T_{z} \mid$ Kembal & status & Nama \\
\hline 20190429001 & 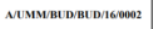 & 216330003 & $29-4+2019$ & 02-205-2019 & pinjam & SARAH SLLAEN \\
\hline 20199503002 & 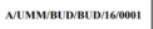 & 216430002 & $27-0.2019$ & 03-56-2019 & pinjam & ANDRE PURBA \\
\hline 201905030005 & AIPSDKK/АRA I7790901 & 216030004 & $27-0+2019$ & 3000+2019 & pinjam & ABDON SIAHA N \\
\hline 201995030006 & NIPSADIARNA17DOOOI & 216430006 & $27-4+2019$ & 300+2019 & pinjam & SAMUEL SILALAH \\
\hline
\end{tabular}
terdiri dari id transaksi, kode buku, id anggota, tgl pinjam, tgl kembali, status, dan nama siswa .

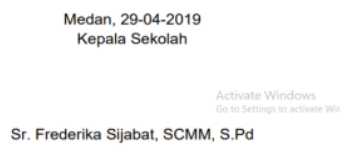

Gambar 16. Tampilan Laporan Transaksi Peminjaman Pada SMA Santo Yoseph Medan

\section{Laporan Daftar Buku Yang Dipinjam Pada SMA Santo} Yoseph Medan

Laporan daftar buku yang dipinjam pada SMA Santo Yoseph Medan ini adalah laporan untuk mengetahui buku apa yang dipinjam dan berapa jumlahnya

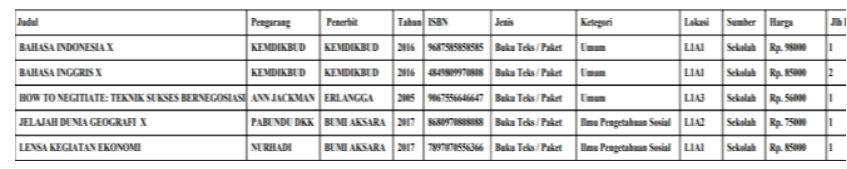

Gambar 17. Tampilan Laporan Daftar Buku Yang Dipinjam

\section{Laporan Denda Anggota SMA Santo Yoseph Medan}

Laporan denda anggota pada SMA Santo Yoseph

Medan ini adalah laporan untuk mengetahui nama siswa yang denda .

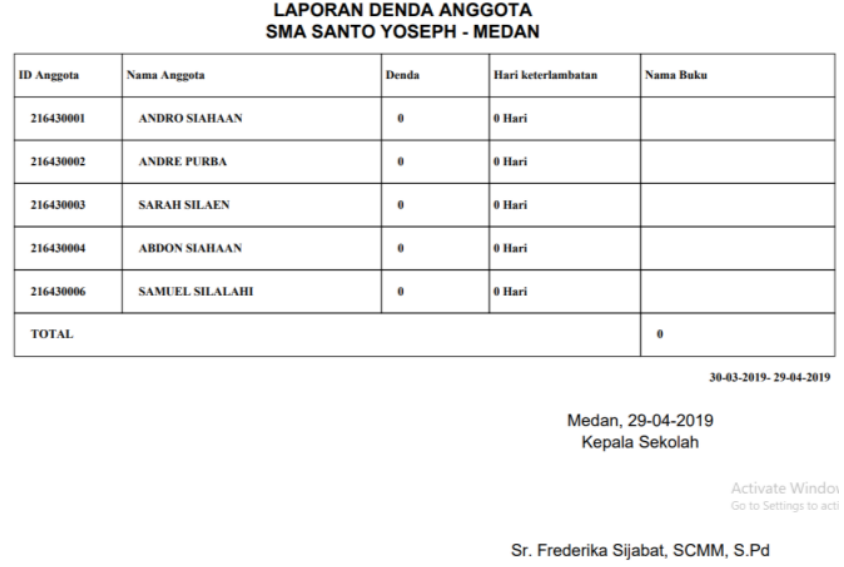

\section{Gambar 18. Tampilan Laporan denda anggota}

\section{Laporan Transaksi Pengembalian Buku Pada SMA} Santo Yoseph Medan

Laporan transaksi pengembalian buku pada SMA Santo Yoseph Medan ini adalah laporan untuk mengetahui nama

\begin{tabular}{|c|c|c|c|c|c|c|}
\hline ID Transaki & Kode Baku & ID Amgrota & TEl Kinjam & TEl Kembali & Statur & sams \\
\hline 201905503001 & 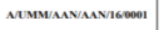 & 216330001 & 27042019 & $30.04-2019$ & kembali & ANDRO SIAHAM \\
\hline 201905303004 $\mathrm{CH}$ & АТМММАN & 216030004 & 27-04:2019 & 2904-2019 & kembati & ABDON SAAHAN \\
\hline
\end{tabular}
siswa yang melakukan pengembalian buku.

LAPORAN TRANSAKSI PENGEMBALIAN BUKU PADA SMA SANTO YOSEPH MEDAN

\section{Medan, 29-04-2019
Kepala Sekolah}

$$
\text { Sr. Frederika Sijabat, SCMM, S.Pd }
$$

Gambar 19. Tampilan Laporan Transaksi Pengembalian Buku

\section{KESIMPULAN}

Dari hasil pembahasan yang telah di uraikan pada bab-bab sebelumnya, maka dapat ditarik kesimpulan sebagai berikut:

1. Dengan adanya sistem informasi perpustakaan yang berbasis web ini, mampu memberikan kemudahan siswa untuk mendapatkan informasi buku yang akan di pinjam melalui web perpustakaan cari buku tanpa harus mencari buku tersebut ke perpustakaan.

2. Sistem informasi perpustakaan yang baru ini memudahkan petugas perpustakaan dalam mengolah data anggota, data buku, transaksi peminjaman dan pengembalian buku, serta perhitungan denda, sehingga dapat menjadi sebuah informasi yang diperlukan bagi pihak yang terkait dengan sistem informasi perpustakaan.

3. Dengan adanya sistem informasi perpustakaan dapat memberikan jangkauan yang lebih luas lagi dalam memberikan data-data buku yang terdapat di perpustakaan SMA Santo Yoseph Medan.

4. Sistem informasi perpustakaan ini memberikan kemudahan bagi petugas perpustakaan dalam pembuatan laporan kegiatan perpustakaannya.

\section{DAFTAR PUSTAKA}

[1] S. Himmah, "istem informasi perpustakaan pada Sekolah Menengah Pertama Negeri I Pakuhaji Tangerang Banten," UIN Syarif Hidayatullah Jakarta, 2006.

[2] I. T. Aziz, "Perancangan Sistem Informasi Pada 
Perpustakaan SMP Negeri 97 Jakarta," Universitas Bina Sarana Informatika (BSI), 2018.

[3] D. E. Hendrianto, "Pembuatan Sistem Informasi Perpustakaan Berbasis Website Pada Sekolah Menegah Pertama Negeri 1 Donorojo Kabupaten Pacitan," IJNSIndonesian J. Netw. Secur., vol. 4, no. 3, pp. 57-64, 2013.

[4] A. Susanto, Sistem Informasi Akuntansi. Bandung: Lingga Jaya, 2013.

[5] M. B. Romney, P. J. Steinbart, and B. E. Cushing, Accounting Information Systems. Boston, MA: Pearson, 2015.

[6] Krismiaji, Sistem Informasi Akuntansi. Yogyakarta: YKPN, 2015.

[7] S. Azhar, Sistem Informasi Akuntansi. Bandung: Lingga Jaya, 2013.

[8] I. K. J. Melani Feruche, DR Manalu, "Sistem Informasi Marketplace Penyewan Properti,” vol. 8, pp. 92-99, 2018.

[9] S. Anwar, S. Maskur, and M. Jailani, Manajemen Perpustakaan. Indragiri: Zahen Publisher, 2019.

[10] Sukamto and Shalahuddin, Analisa dan Desain Sistem Informasi. Yogyakarta: Andi Offset, 2013.

[11] Yakub, Pengantar Sistem Informasi. Yogyakarta: Graha Ilmu, 2012.

[12] Mulyadi, Sistem Akuntansi. Jakarta: Salemba Empat, 2016. 